\title{
Tren Layanan Referensi Virtual \\ Studi Kualitatif Pada 12 Website Perpustakaan di Pulau Jawa
}

Katrin Setio Devi, Indira Irawati

Departemen Ilmu Perpustakaan dan Informasi Fakultas Ilmu Pengetahuan

Budaya, Universitas Indonesia, Depok, Jawa Barat

katrinsetiodevi@gmail.com

\begin{abstract}
The virtual reference service (VRS) has been implemented by some libraries in Indonesia. This study aims to identify trends in VRS in some libraries in the Java Island. This research is a qualitative study using descriptive analysis presented as a percentage, then elaborated again with narration or description associated with the field and theory. Using purposive sampling technique, selected 12 libraries to be analyzed on the website. The sample consists of public libraries and special libraries. The results form 12 library samples found to bring trends in the form of presenting referral services if sorted from the most used by the library are email (91\%), web forms (75\%), chat references (67\%), and SMS (8\%). Both email and web form used for VSR is using the library's public email. Chat references available on the web library use the Tawk Live Chat App, add on Dalet Galaxy, Whatsapp and Line. VRS in SMS form is only used by the National Library. Email is the most common format used as a communication tool in VRS followed by web forms, chat references and SMS. The results of this study can be used as material for consideration to develop format of VRS in Indonesian libraries.
\end{abstract}

Keywords : Virtual Reference Service; Library; Indonesia

\begin{abstract}
Abstrak
Layanan referensi virtual telah diterapkan oleh beberapa Perpustakaan di Indonesia. Kajian ini bertujuan untuk mengidentifikasi tren layanan referensi virtual di perpustakaan wilayah Pulau Jawa. Penelitian ini merupakan kajian kualitatif yang menggunakan analisis deskriptif, disajikan dengan persentase, lalu dijabarkan lagi dengan narasi atau deskripsi yang dikaitkan dengan data lapangan dan teori. Menggunakan teknik purposive sampling, terpilih 12 perpustakaan yang akan dianalisis websitenya. Sampel terdiri dari perpustakaan umum dan perpustakaan khusus. Dari 12 sampel perpustakaan ditemukan bawa tren bentuk penyajian layanan rujukan jika diurutkan dari yang terbanyak digunakan oleh perpustakaan adalah email (91\%), web form (75\%), chat reference (67\%), dan SMS (8\%). Email yang digunakan oleh perpustakaan mayoritas menggunakan email umum perpustakaan, begitu
\end{abstract}


juga pada web form. Chat reference yang ada pada web perpustakaan menggunakan Live Chat App Tawk, add on Dalet Galaxy, Whatsapp dan Line. Jenis penyajian melalui SMS untuk layanan referensi virtual hanya dipraktikkan Perpustakaan Nasional. Email adalah bentuk paling umum yang digunakan sebagai alat komunikasi dalam layanan referensi virtual disusul oleh web form, chat reference dan SMS. Hasil penelitian ini dapat digunakan sebagai bahan pertimbangan untuk mengembangkan bentuk layanan referensi virtual di perpustakaan Indonesia.

Kata Kunci: Layanan Referensi Virtual; Perpustakaan; Indonesia

\section{A. PENDAHULUAN}

Layanan referensi atau layanan rujukan merupakan layanan krusial di perpustakaan untuk membimbing pemustaka dalam menggunakan informasi atau koleksi yang perpustakaan miliki (Nugrahini: 2013). Seiring dengan kemajuan teknologi, muncul dimensi baru dalam penyajian layanan referensi, yaitu VRS (Virtual Reference Service) yang merupakan modifikasi layanan rujukan di perpustakaan yang dulunya hanya dapat dilakukan secara tatap muka (fisik) menjadi konsultasi secara virtual (Yang dan Dalal : 2014). Layanan ini telah banyak diadopsi oleh perpustakaan di seluruh dunia, termasuk di Indonesia. Banyak kajian telah dilakukan oleh para peneliti, akademisi dan praktisi untuk membahas layanan referensi virtual. Beberapa penelitian membahas mengenai evaluasi layanan ini, salah satunya adalah penelitian dari Qomariah dan Kusuma (2015) yang meneliti layanan referensi virtual melalui e-mail di Perpustakaan UK Petra Surabaya. Kajian dilakukan dengan analisis konten pada interaksi antara pemustaka dan pustakawan melalui transkrip e-mail. Analisis dilakukan dengan kategorisasi jenis pertanyaan dan gaya komunikasi. Hasil menunjukan bahwa jenis pertanyaan yang berkaitan dengan konsultasi (layanan referensi) sebesar $16,67 \%$, untuk sisanya berupa pertanyaan mengenai layanan sirkulasi dan teknis lainnya. Ditemukan juga bahwa gaya bahasa dalam interaksi yang digunakan adalah formal atau terkesan kaku.

Selain itu juga ada kajian literatur yang dilakukan oleh Wicaksono (2017) yang membahas mengenai praktik layanan referensi virtual melalui SMS. Hasil penelitian ini digunakan untuk bahan pertimbangan dalam penggunaan layanan referensi virtual melalui media SMS guna membuka seluas-luasnya kesempatan kepada pemustaka untuk bertanya ke 
perpustakaan dalam rangka pemenuhan kebutuhan informasinya. Hasil penelitian menunjukkan ada beberapa perpustakaan di Indonesia yang telah menggunakan media SMS dalam melakukan layanan referensi, salah satunya adalah Perpustakaan Nasional. Dalam praktik penggunaanya, ditemukan fakta bahwa pemanfaatan bentuk layanan ini masih minim karena adanya kesenjangan digital di Indonesia. Persentase penggunaan SMS dalam layanan ini masih kalah dengan penggunaan email. Berbeda dengan penelitian sebelumnya yang fokus membahas penelitian referensi virtual yang ada di Perpustakaan Nasional, penelitian ini akan mengkaji jenis-jenis media yang digunakan oleh 12 perpustakaan di Pulau Jawa, hasilnya akan dipresentasekan secara deskriptif jadi akan terlihat tren layanan referensi virtual.

Kajian yang telah dilakukan dalam ranah layanan referensi virtual ini mayoritas membahas mengenai bentuk layanan dan implementasinya di Perpustakaan lalu evaluasi dari layanan tersebut. Terlihat bahwa sejauh ini di dalam kajian hanya ada dua media dalam penyampaian layanan referensi virtual yaitu SMS dan Email. Belum terlihat apakah ada bentuk lain dalam praktik layanan ini, terlebih lagi dilihat dari kemajuan teknologi dan sisi perpustakaan khusus yang mempunyai kebijakan dan kepentingan yang berbeda dari perpustakaan umum. Berdasarkan latar belakang tersebut, peneliti telah mengkaji mengenai tren layanan yang telah dilakukan oleh perpustakaan di Indonesia. Pertanyaan penelitiannya adalah "Bagaimana tren layanan referensi virtual yang ada pada perpustakaan di Pulau Jawa?". Dari kajian ini terlihat beberapa bentuk VRS dari beragam jenis perpustakaan (Perpustakaan Umum dan Perpustakaan Khusus) di pulau Jawa. Hasil penelitian ini dapat digunakan sebagai bahan pertimbangan untuk mengembangkan bentuk VRS di perpustakaan Indonesia dengan menyesuaikan bentuk atau jenis perpustakaan dan pengguna di dalamnya.

Penelitian ini merupakan kajian kualitatif yang menggunakan analisis deskriptif yang disajikan dengan persentase, lalu dijabarkan lagi dengan narasi atau deskripsi yang dikaitkan dengan data lapangan dan teori (praxis). Sebelum menganalisis 12 web perpustakaan, peneliti melakukan kajian literatur mengenai layanan referensi virtual. Pra-research ini dilakukan untuk melihat konseptualisasi dari layanan tersebut. Secara umum penelitian ini 
bertujuan untuk mengidentifikasi tren layanan referensi virtual di perpustakaan wilayah Pulau Jawa. Menggunakan teknik purposive sampling, terpilih 12 perpustakaan yang akan dianalisis websitenya. Data diambil dari website Perpustakaan Nasional, Dinas Perpustakaan dan Kearsipan Daerah Provinsi Banten, Dinas Perpustakaan dan Kearsipan Daerah Provinsi Jawa Barat, Dinas Perpustakaan dan Kearsipan Daerah Provinsi Jawa Tengah, Dinas Perpustakaan dan Kearsipan Daerah Istimewa Yogyakarta, Dinas Perpustakaan dan Kearsipan Daerah Provinsi Jawa Timur, Lembaga Ilmu Pengetahuan Indonesia, Perpustakaan MetroTv, Perpustakaan Universitas Indonesia, Perpustakaan Universitas Brawijaya, Perpustakaan Universitas Bina Nusantara dan Perpustakaan Universitas Pelita Harapan. Pengambilan data dilakukan dengan jangka periode 1 bulan (1 April 2020-1 Mei 2020), untuk menghindari adanya perubahan (konsistensi) isi web.

Penelitian ini hanya meneliti perpustakaan yang berada di pulau jawa dengan sampel terbatas. Hasil tidak dapat digeneralisasikan ke seluruh Perpustakaan di Indonesia mengingat grafik perkembangan ekonomi dan pendidikan di Pulau Jawa yang lebih maju dari daerah lain di Indonesia. Hal tersebut tentunya akan mempengaruhi kondisi perkembangan layanan yang dapat diberikan oleh perpustakaan karena keberadaan sumber daya yang tersedia.

\section{B. HASIL DAN PEMBAHASAN}

\section{Layanan Referensi Virtual}

Berbeda dengan layanan referensi konvensional yang harus bertatap muka secara langsung (fisik), layanan referensi virtual memungkinkan pemustaka untuk mengajukan pertanyaan dan menerima jawaban melalui internet atau media elektronik lainnya. Arwendria (2019) menyatakan bahwa referensi virtual mengacu pada proses pemenuhan kebutuhan pemustaka dengan menyediakan layanan bimbingan secara virtual.

Menurut Fan dan Welch (2016) layanan referensi virtual atau AskA adalah layanan tanya jawab berbasis internet yang menghubungkan pemustaka dengan pustakawan atau para ahli pada berbagai bidang tertentu (subject specialist). Selain menjawab pertanyaan, para pustakawan/subject specialist juga dapat memberikan rujukan kepada pengguna akan sumber informasi cetak atau digital yang sesuai dengan kebutuhan pengguna. 
Dengan demikian, dengan adanya layanan referensi virtual, pemustaka dan pustakawan/subject specialist/profesional informasi dapat berinteraksi untuk melakukan konsultasi yang tidak terbatas pada tempat dan waktu. Ahli informasi juga dapat memberikan bimbingan atau rujukan kepada pengguna untuk kemudahan akses sumber informasi untuk meningkatkan keterampilan literasi informasi (Zuntriana: 2018). Menurut Rahmi (2019), dalam pelaksanaan layanan referensi virtual ada beberapa komponen yang ada didalam prosesnya, yaitu pengguna, ahli informasi, platform layanan virtual, dan sumber informasi. Dapat disimpulkan bahwa layanan referensi virtual adalah layanan yang memungkinkan pustakawan dan pemustaka untuk berkomunikasi satu sama lain secara virtual melalui internet dengan email, obrolan atau pesan instan yang bertujuan untuk memberikan pelayanan jarak jauh, tanpa ada batasan tempat dan waktu.

\section{Jenis VRS}

Ada berbagai bentuk atau media dalam praktik melayanakan VSR. Menurut Arya (2012) ada tiga kategori dalam VSR, yaitu:

1. Transaksi Asynchronous: ada jeda waktu antara pertanyaan yang diajukan dan jawaban . Contoh :

a. E-mail: pemustaka mengirimkan pertanyaan kepada pustakawan/subject specialist/profesional informasi melalui email. Layanan referensi email populer dari perspektif pengguna karena mudah diakses, tidak memerlukan perangkat lunak tambahan, tidak berbahaya (keamanan), dan pertanyaannya dapat dinyatakan dalam gaya bahasa pengguna sendiri. Dari perspektif pustakawan, layanan referensi berbasis e-mail mudah diterapkan, dan tidak diperlukan pelatihan tambahan.

b. Web Form: satu bagian dari web yang merupakan tempat bagi pengguna untuk menuliskan pertanyaan mereka, berbentuk formulir yang akan muncul jika diklik. Informasi spesifik lainnya (misalkan nama, alamat email) juga harus diisi bersama dengan pertanyaan. Formulir yang sudah diisi kemudian dikirim ke perpustakaan dengan mengklik tombol 
"kirim/submit". Formulir web menyediakan format sistematis. dan memfasilitasi framing dari pertanyaan.

c. Ask A Service: merupakan situs web/media yang disponsori perusahaan yang memungkinkan pengguna untuk mengajukan pertanyaan dan menerima jawaban secara gratis dari informasi publik yang sebagian besar terletak di World Wide Web atau dari database dan profesional informasi/subject specialist.

2. Transaksi Synchronous: layanan real-time, adanya respons atau jawaban yang hampir seketika (waktu yang sama) terhadap pertanyaan atau permintaan dari pengguna. Contoh:

a. Chat Reference (menggunakan teknologi sederhana): pustakawan referensi dan pemustaka dapat berkomunikasi satu sama lain menggunakan pesan teks singkat secara real time menggunakan bantuan perangkat lunak.

b. Chat Reference (menggunakan web contact software): perangkat lunak memungkinkan untuk pengiriman pesan instan, dan juga memungkinkan penelusuran kolaboratif antara pustakawan dan pemustaka. Sistem biasanya terdiri dari layar terbagi di mana dalam satu layar pustakawan dan pemustaka dapat saling melihat pertanyaan dan tanggapan yang diketikkan, dengan layar lainnya menampilkan halaman web, atau sumber informasi elektronik lainnya, atau layar katalog perpustakaan.

c. Layanan konferensi video atau kamera web: pustakawan dan pemustaka dapat saling melihat dalam satu jendela monitor melalui kamera. Situs web atau sumber daya elektronik lainnya dapat ditampilkan di jendela lain pada monitor.

d. Digital Reference Robots: menggunakan prinsip-prinsip artificial intelligence untuk menjawab pertanyaan. Seorang pemustaka mengetik pertanyaan, dan sistem menafsirkannya dengan meminta pengguna untuk memilih dari serangkaian pertanyaan dengan kata yang berbeda. Berdasarkan pilihan, jawaban kemudian diberikan. 
3. Layanan Referensi Digital Kolaboratif: dua atau lebih perpustakaan bekerja sama untuk menawarkan layanan referensi menggunakan salah satu format di atas. Pemustaka akan mengirim permintaan ke perpustakaan anggota, yang akan diteruskan ke perpustakaan anggota yang paling mampu menjawab pertanyaan. Perpustakaan dapat menerima pertanyaan karena memiliki kekuatan domain, atau bahwa itu mungkin terletak di zona waktu lain yang terbuka ketika pemustaka mengajukan pertanyaan. Contohnya adalah Cobrowsing/escorting dan Web page pushing.

\section{Jenis Layanan Referensi Virtual di Perpustakaan Indonesia Wilayah Pulau Jawa}

Data yang didapatkan dari lapangan adalah $91 \%$ perpustakaan menggunakan email, 75\% menggunakan web form, $67 \%$ Chat Reference dan $8 \%$ SMS. Data yang berhasil dihimpun berasal dari berbagai jenis perpustakaan (perpustakaan umum dan khusus), tidak ada intensi spesifik dalam keragaman ini. Peneliti mengkaji website perpustakaan yang memang sudah menyediakan layanan referensi virtual. Tampilan web perpustakaan beragam, ada beberapa yang sudah menerapkan konsep interface dengan baik, sehingga pengunjung web tidak kesulitan dalam menemukan menu atau layanan yang disediakan dalam website perpustakaan. Layanan referensi virtual ada yang mudah ditemukan di web, namun ada yang tersembunyi, harus mengklik beberapa menu sebelum mencapai pada bagian laman yang dapat melayani pemustaka dalam bidang layanan konsultasi atau bimbingan pengguna. Dari 12 perpustakaan tersebut, tidak semua menggunakan istilah layanan referensi virtual, ada yang menyebutkan layanan tersebut sebagai "konsultasi pustakawan", "tanya-jawab pustakawan" dan "layanan bimbingan". Berikut adalah pembahasan dari data yang sudah dikategorikan dalam dua bentuk praktik layanan referensi virtual:

1. Layanan

Asynchronous

Dalam dimensi layanan referensi virtual ada bentuk layanan yang disajikan dengan jeda waktu respon antara pertanyaan dan jawaban dari interaksi yang dilakukan oleh pemustaka dan pustakawan. Dari 
data yang diperoleh, $91 \%$ atau 11 dari 12 perpustakaan menggunakan bentuk layanan ini. Satu perpustakaan yang tidak menggunakan bentuk penyajian ini adalah perpustakaan Metro TV. Keberadaan perpustakaan atau yang diistilahkan dengan DLC (Digital Library Centre) Metro TV berfungsi sebagai penyedia layanan referensi dokumentasi atau materi yang berbentuk audio-visual untuk membantu pengguna (yang terdiri dari produser, jurnalis, editor dan staf lainnya) dalam melakukan riset berkaitan dengan pembuatan konten yang akan disajikan di portal media massa. Walaupun tidak menggunakan bentuk layanan asynchronous, DLC Metro TV menggunakan format lain yang akan dibahas pada bagian layanan real-time. Ada beberapa bentuk layanan asynchronous yang ditemukan dalam kajian ini, berikut penjabarannya:

\section{a. E-mail}

Dapat dikatakan bahwa email adalah bentuk paling umum yang digunakan sebagai alat komunikasi dalam layanan referensi virtual. Hasil di lapangan menyatakan bahwa $91 \%$ menggunakan bentuk ini. Bisa simpulkan bahwa $100 \%$ dari penyajian layanan referensi virtual secara asynchronous dilakukan dengan menggunakan email. Ada beberapa perpustakaan yang menggunakan email khusus untuk memberikan layanan referensi virtual, seperti Perpustakaan Nasional (layanan_referensi@perpusnas.go.id) dan Perpustakaan Universitas Indonesia (refdesk.lib@ui.ac.id). Selain kedua perpustakaan tersebut, 9 perpustakaan lain menggunakan email yang sama dengan email perpustakaan, ini mengindikasikan alamat e-mail umum, tidak hanya untuk layanan referensi virtual. Walaupun menggunakan alamat email perpustakaan, di beberapa perpustakaan mencantumkan keterangan bahwa email tersebut dapat digunakan jika pemustaka ingin berkonsultasi kepada pustakawan, contohnya pada Dinas Perpustakaan dan Kearsipan Daerah Provinsi Jawa Barat. Dengan menggunakan media email ini memungkinkan pemustaka untuk mengirimkan pesan setiap 
saat untuk pustakawan yang tidak dalam keadaan online (mayoritas perpustakaan di Indonesia tidak beroperasi selama 24 jam) atau tidak online pada waktu yang sama.

b. Web

Form

Sebanyak 9 perpustakaan atau jika diprosentasekan sejumlah $75 \%$ menggunakan bentuk formulir web untuk memberikan layanan referensi virtual kepada pemustaka. Perpustakaan yang memberikan bentuk penyajian layanan ini adalah Perpustakaan dan Kearsipan Daerah Provinsi Banten, Perpustakaan dan Kearsipan Daerah Provinsi Jawa Barat, Perpustakaan dan Kearsipan Daerah Provinsi Jawa Tengah, Perpustakaan dan Kearsipan Daerah Istimewa Yogyakarta, LIPI, Perpustakaan Universitas Brawijaya, dan Perpustakaan Universitas Pelita Harapan. Mayoritas tampilan untuk formulir web ini berada pada menu "kontak kami". Menu ini selalu ada pada halaman utama yang letaknya ada pada bagian atas web sehingga mudah untuk ditemukan. Sebagai contoh, pada Dinas Perpustakaan dan Arsip Provinsi Jawa Timur, di menu website ada salah satu menu Kontak, lalu ada sub menunya forum/saran. Menu tersebut mempunyai dua pilihan, yaitu tanya jawab dan kritik saran. Kedua pilihan menu tersebut mengantarkan pada halaman baru (new tab) yaitu halaman tanya jawab dan buku tamu. Kedua halaman ini menampilkan formulir online yang berisi title, isi, email, dan pengirim yang harus diisi bagi pengguna yang ingin melakukan konsultasi.

\section{c. SMS}

Perpustakaan Nasional adalah satu-satunya perpustakaan yang menggunakan bentuk penyajian layanan referensi virtual dengan menggunakan SMS (8\%). Merupakan salah satu bentuk penyajian layanan anyschronous, SMS memiliki karakteristik, yaitu sifatnya yang tidak sinkronis, respon yang tidak menentu, dan keterbatasan karakter (kata). Metode ini telah digunakan oleh Perpustakaan Nasional sejak tahun 2012. 
Oleh Perpustakaan nasional (perpusnas.go.id), dikatakan bawa penggunaan media SMS dalam layanan referensi ini diharapkan dapat membuka kesempatan seluas-luasnya bagi masyarakat untuk bertanya kepada Perpustakaan Nasional dalam rangka memenuhi kebutuhan informasi mereka. Semua bentuk layanan referensi virtual perpustakaan nasional dapat diakses pada laman https://pusjasa.perpusnas.go.id/tanyapustakawan/.

\section{Transaksi Synchronous}

Layanan yang biasa disebut dengan layanan real-time atau dengan kata lain dalam waktu yang sama pemustaka dapat mendapatkan jawaban atau respons dari pustakawan atas pertanyaan yang ia ajukan. Hasil menunjukan bahwa 8 perpustakaan atau sebesar $67 \%$ menggunakan cara penyajian layanan referensi virtual dengan menggunakan metode ini. Perpustakaan tersebut adalah Perpustakaan Nasional, Dinas Perpustakaan dan Kearsipan Provinsi Jawa Barat, Perpustakaan Universitas Indonesia, DLC Metro TV, LIPI, Perpustakaan Universitas Indonesia, Perpustakaan Universitas Bina Nusantara, Perpustakaan Universitas Brawijaya, dan Perpustakaan Universitas Pelita Harapan. Berikut adalah penjabarannya:

\section{a. Chat}

Reference

Berdasarkan data, $67 \%$ atau 8 perpustakaan menggunakan bantuan teknologi (software) untuk menyajikan layanan referensi virtual ini. Mayoritas perpustakaan menggunakan bantuan //www.tawk.to/. Tawk adalah salah satu live chat app yang digunakan untuk berinteraksi secara real time oleh pengunjung dengan pemilik website, atau dalam kajian ini adalah interaksi antara pemustaka dan pustakawan. Cara kerja dari bentuk penyajian layanan ini sangat simple, pemustaka seperti melakukan chat biasa, bertanya kepada pustakawan dengan mengirimkan pesan pada kolom chat yang akan seketika muncul ketika kita berkunjung ke website perpustakaan, contohnya di website Perpustakaan Nasional, 
kita akan langsung disambut dengan ucapan selamat datang dan dipersilahkan untuk bertanya jika ada hal yang belum jelas atau ingin berkonsultasi kepada pustakawan. Bentuk chat tidak sekaku pada formulir web yang harus menyertakan nama, email dan identitas lainnya. Pengguna boleh tidak menyertakan identitas seperti yang ada pada web form.

Telah dibahas sedikit pada poin sebelumnya bahwa DLC Metro TV menggunakan bentuk penyajian layanan referensi virtual tidak dengan menggunakan tipe layanan asynchronous, namun menggunakan bentuk live chat. Aplikasi add on yang digunakan oleh instansi ini adalah Dalet Galaxy. Aplikasi ini adalah evolusi terbaru dari platform Dalet Galaxy Media Asset Management (MAM) dan Workflow Orchestration yang menyatukan rantai konten dengan mengelola aset, metadata, alur kerja, dan proses di berbagai sistem produksi dan distribusi yang beragam. Dirancang khusus untuk alur kerja media, platform teknologi unik ini membantu penyiar dan profesional media meningkatkan produktivitas mereka sambil memberikan visibilitas operasional dan bisnis. Ini biasa digunakan dalam instansi broadcasting untuk menyokong kebutuhan para pengguna di dalam instansi untuk membuat paket data.

Empat Perpustakaan lainnya menggunakan bantuan free messaging app seperti Whatsapp dan Line. Yang unik adalah perpustakaan Universitas Pelita Harapan yang tidak menyertakan nomor whatsapp atau id line di laman informasi untuk akses layanan, mereka memberikan barcode yang dapat di scan oleh pemustaka. Ini adalah bentuk keterbaharuan yang akan disukai oleh para pemustaka karena generasi milenial mendambakan hal praktis, tanpa menulis nomor Whatsapp atau id Line pada aplikasi messenger, pengguna tinggal menscan barcode tersebut, secara instant mereka sudah terhubung dengan layanan referensi virtual yang dimiliki perpustakaan universitas pelita harapan. 
Yang harus diperhatikan dalam bentuk penyajian layanan ini adalah pemustaka hanya dapat mengajukan pertanyaan dalam jangka waktu jam operasional perpustakaan, mayoritas perpustakaan di Indonesia tidak buka selama 24 jam. Jika sudah melewati jam operasional perpustakaan, maka dengan otomatis chat akan "offline", pemustaka tidak akan dapat mengakses layanan ini. Sedikit berbeda dengan kasus untuk whatsapp dan line, mungkin pesan akan tetap dapat terkirim, namun tidak ada pustakawan yang akan menjawabnya.

\section{Layanan Referensi Virtual dalam Implementasinya Pada 12 Web Perpustakaan di Pulau Jawa}

Perpustakaan memberikan berbagai bentuk penyajian untuk layanan referensi virtual dengan tujuan mencapai pengguna potensial agar dapat memanfaatkan layanan walaupun mereka memiliki keterbatasan waktu untuk datang ke perpustakaan. Tugas pustakawan referensi di sini adalah mengarahkan pemustaka untuk menemukan sumber informasi yang mereka butuhkan sehingga fungsi perpustakaan dapat berjalan secara optimal. Tren yang terlihat dari hasil penelitian menunjukkan bentuk layanan asynchronous email menjadi peringkat pertama. Dengan menggunakan email, penghalang psikologis yang menghambat pemustaka yang pemalu dalam mengajukan pertanyaan menjadi hilang. Selain itu, tidak semua pengguna memiliki komunikasi lisan yang baik, mereka lebih leluasa dalam menyampaikan pertanyaan melalui tulisan. Dari pihak perpustakaan, dengan perangkat email ini yang notabene gratis dan bisa mudah diakses dan digunakan oleh semua kalangan dapat menghemat biaya operasional karena penggunaan email tidak perlu adanya pelatihan tambahan. Para pustakawan referensi memiliki waktu lebih dalam meramu jawaban dari pertanyaan pemustaka karena sifat email yang tidak real-time. Mayoritas pada web perpustakaan yang menjadi sampel mengatakan bahwa layanan referensi virtual ditujukan untuk para pengguna yang memiliki keterbatasan waktu untuk mengunjungi perpustakaan. Dengan layanan ini, perpustakaan bermaksud untuk menghapus batasan waktu, pemustaka dapat bertanya kapan saja. 
Mayoritas dari perpustakaan yang menjadi sampel menggunakan alamat email umum perpustakaan, ini menjadi indikasi bahwa pengguna tidak hanya dapat berkonsultasi kepada pustakawan, tetapi mereka juga dapat menanyakan hal-hal umum yang tidak berkaitan dengan layanan rujukan. Ini dapat menjadi pertanyaan, siapa pustakawan yang menjawab email tersebut. Tentu email tidak dapat dibuka oleh sembarangan atau semua staff di perpustakaan. Jika memang yang memegang kuasa email tersebut adalah pustakawan referensi, tidak akan ada masalah ketika ada pertanyaan yang berkaitan dengan layanan referensi. Namun beban kerja pustakawan referensi akan ganda ketika ada pertanyaan umum yang masuk pada email tersebut. Begitu pula sebaliknya, jika yang memegang kendali adalah pustakawan TI, mereka harus menyortir pertanyaan berdasarkan jenis, lalu mendistribusikan kepada bidang atau divisi yang dipertanyakan oleh pemustaka, hal tersebut akan memakan waktu dan tenaga.

Pemaknaan ini juga berlaku pada bentuk tren peringkat kedua, yaitu layanan referensi virtual yang penyajiannya menggunakan web form. Walaupun bentuknya berbeda, namun sistematika alurnya mirip dengan email. Yang membedakan hanya jika email pemustaka perlu membuka aplikasi email (yahoo/gmail), pada web form ini pengguna hanya perlu mengisi formulir yang ada di web perpustakaan. Berdasarkan hasil di lapangan, mayoritas perpustakaan menjadikan satu layanan referensi dengan layanan umum, karena di sana pengunjung juga dapat memberikan kritik dan saran (ada dalam kategori formulir tersebut). Fakta tersebut mengarahkan pada ketidakefektifan layanan seperti yang dijabarkan pada analisis email yang menggunakan email umum perpustakaan. Pembahasaan pengantar yang ada pada email dan web form yang baku secara tidak langsung menuntut para pengguna untuk menggunakan bahasa formal.

Pada tren peringkat ketiga, chat reference, telah diadopsi beberapa perpustakaan di Indonesia. Dengan fasilitas ini, pengguna dapat mendapatkan respon dari pustakawan referensi secara real-time, yang dapat diartikan bahwa kecepatan layanan ini lebih cepat daripada layanan email, sehingga pengguna tidak perlu menunggu tanggapan dalam waktu yang relatif lama. Pustakawan referensi dapat melayani lebih dari satu pemustaka. Ada beberapa software gratis yang dapat dimanfaatkan untuk ditambahkan 
pada website perpustakaan seperti yang sudah dijelaskan di atas. Penggunaan chat reference ini akan diminati oleh para kawula muda yang terbiasa mendapatkan jawaban akan pertanyaan mereka secara instan. Gaya bahasa yang digunakan juga tidak formal seperti ketika kita menggunakan email, karena masyarakat menggunakan chat messenger dalam kehidupan seharihari untuk berkomunikasi dengan bebas, tidak terikat formalitas. Perpustakaan tidak perlu menambahkan anggaran dalam penambahan fitur ini karena dapat didapatkan secara gratis. Pendidikan pengguna juga tidak perlu dilakukan karena masyarakat sudah terbiasa dalam menggunakan chat messenger dalam kehidupan sehari-hari. Dengan menggunakan layanan ini, perpustakaan juga dapat lebih mendekatkan diri kepada masyarakat karena image ramah akan tercipta, setiap pengunjung yang hadir pada web akan ditanyai mengenai kebutuhan mereka dan apa yang perpustakaan dapat bantu untuk memenuhi kebutuhan tersebut.

Hanya ada di Perpustakaan Nasional, layanan rujukan yang disajikan dengan SMS, menduduki peringkat terakhir dalam tren. Merupakan salah satu bentuk layanan asynchronous, SMS telah diadopsi oleh perpustakaan nasional sejak tahun 2012. Bentuk pelayanannya lebih terbatas daripada beberapa bentuk yang telah dijabarkan di atas, salah satunya adalah keterbatasan kuantitas karakter pada teks yang dapat dikirim. Jika dilihat dari sudut pandang teknologi, bentuk layanan ini masuk pada kategori tidak sejalan dengan kemajuan zaman, kurang efektif untuk dijalankan. Banyak masyarakat yang meninggalkan fitur ini (untuk komunikasi sehari-hari) karena keterbatasan teks yang bisa terkirim, dan membutuhkan biaya (pulsa). Namun ini masih dalam kategori efektif jika kita dihadapkan pada pengguna yang gagap teknologi, biasanya para orang tua atau masyarakat dengan golongan menengah kebawah yang tidak mempunyai biaya dalam mengakses atau membeli gadget terbaru. Perpustakaan Nasional yang merupakan pusat informasi negara cukup bijak dalam memberikan layanan, tidak hanya memberikan layanan chat reference yang canggih, mereka juga menyediakan layanan SMS sehingga dapat membuka kesempatan seluasluasnya bagi masyarakat (tanpa memandang golongan) untuk bertanya kepada Perpustakaan Nasional dalam rangka memenuhi kebutuhan informasi mereka. Layanan referensi dengan beberapa model (SMS, Email, dan Chat Reference)yang diberikan oleh Perpustakaan Nasional akan meningkatkan peran mereka sebagai agen inklusi informasi.

\section{KESIMPULAN}


Layanan referensi virtual telah diterapkan di Indonesia. Data penelitian ini didapatkan dari 12 web perpustakaan yang telah dipilih dengan beberapa kriteria, salah satunya adalah sudah menyediakan layanan referensi rujukan. Tujuan dari penelitian ini adalah untuk melihat tren layanan referensi virtual yang diberikan oleh 12 sampel perpustakaan, hasil ditemukan bawa tren bentuk penyajian layanan rujukan jika diurutkan dari yang terbanyak digunakan oleh perpustakaan adalah sebagai berikut: email (91\%), web form (75\%), chat reference (67\%), dan SMS (8\%). Dapat dikatakan bahwa email adalah bentuk paling umum yang digunakan sebagai alat komunikasi dalam layanan referensi virtual. Penelitian lanjutan yang dapat dilakukan berdasarkan penelitian ini adalah kajian perspektif pengguna akan layanan referensi virtual dan melihat kecenderungan atau favorit mereka dalam memperoleh layanan. Lalu faktor apa saja yang mempengaruhi pilihan mereka. Hasil dapat dijadikan panduan dalam mengembangkan layanan yang sesuai dengan keinginan dan kebutuhan pengguna.

\section{DAFTAR RUJUKAN}

Arwendria, A. (2019). Identifikasi Kompetensi Pustakawan Digital Berdasarkan Analisis Pekerjaan Pustakawan dari Tahun 2016-2018 di Indonesia. Jurnal Maktabatuna. 1(1), 24-38.

Arya, Harsh Bardhan., Mishra, J. K. (2012). Virtual Reference Services: Tools and Techniques. International Research. Journal of Library \& Information Science. 2 (1), 102-115.

Fan, Suhua C., Welch, Jennifer M. (2016). Content Analysis of Virtual Reference Data: Reshaping Library Website Design. Journal Medical Reference $\quad$ Services Quarterly. 35 (3), 294-304.

Nugrahini, Nining. (2013). Layanan Referensi Dan Promosi Koleksi Referensi. Materi Pelatihan Peningkatan Mutu Tenaga

Pustakawan STAH Santika Dharma Malang. Universitas Negeri Malang. Diakses 21 Mei, 2020, dari http://library.um.ac.id/images/stories/pustakawan/pdfnining/layanan\% 20referensi.pdf. 
Qomariyah, Astutik Nur and Kusuma, Rusdiyah Ciptaning Dwi. (2015). Analisis Transaksi E-mail dalam Layanan Referensi Virtual. Record and Library Journal. 1(2), 105-119.

Rahmi, L. (2019). Evolusi Layanan Referensi Dan Informasi Pada Perpustakaan Perguruan Tinggi. Turast: Jurnal Penelitian dan Pengabdian, 7(2), 161-176

Vardeman, Kimberly \& Barba, Ian. (2015). Reference in 160 Characters or Less: The Role of Text Messaging in Virtual Reference Services. Journal Internet Reference Services Quarterly. 19 (3-4), 163-179.

Wicaksono, A. (2017). Layanan Referensi Melalui SMS: Studi Literatur. Jurnal Media Pustakawan. 24 (1), 4-11.

Wicaksono, A. (2017). Dimensi relasi dalam transaksi referensi di SMS Center Perpustakaan Nasional RI. Tesis. Universitas Indonesia.

Yang, Sharon \& Dalal, Heather. (2014). Delivering Virtual Reference Services on The Web: An Investigation into the Current Practice by Academic Libraries. The Journal of Academic Librarianship. 41(1), 68-86.

Zuntriana, A. (2018). Remote Usability Testing Portal Web of Perpustakaan Nasional Republik Indonesia. Record and Library Journal, 1(1), 6876. 